\title{
Süt Ortamında Lactobacillus plantarum NRRLB 4496'nın Aflatoksin M1 (AFM1) Bağlama Potansıyeli
}

\author{
Nergiz Yüksel $^{{ }^{*}} \quad$ Çisem Bulut Albayrak ${ }^{1}$ \\ 1:Aydın Adnan Menderes Üniversitesi, Mühendislik Fakültesi, Gıda Mühendisliği Bölümü, 09100 Aydın, Türkiye \\ *Sorumlu yazar: nergiz.yuksel@adu.edu.tr \\ ${ }^{1}$ https://orcid.org/0000-0002-1334-051x, ${ }^{2}$ https://orcid.org/0000-0002-7993-5372
}

Mikotoksinler, bazı fungus türleri tarafindan sentezlenen ikincil metabolitlerdir ve bu toksinler içinde aflatoksinler insan ve hayvan sağlığı için çok tehlikeli olarak bilinmektedir. Aflatoksin M1(AFM1) kontaminasyonu süt ve süt ürünlerinde kritik rol oynamaktadır. Bu çalışmanın amacı, Lactobacillus plantarum NRRLB 4496'nın yağsız süt örneklerinde AFM1'in uzaklaştırma yeteneğinin değerlendirilmesidir. Süt ortamında AFM1 bağlanması, farklı parametreler ile test edilmiştir; AFM1 konsantrasyonları $(0,5,1,2,5,10 \mathrm{ppb})$ ve inkübasyon süresi (30 dk, 1sa, 6sa, 24sa, $48 \mathrm{sa})$. Sütte kalan bağlanmamı̧ AFM1 miktarı, florans detektörlü yüksek performans sıvı kromatografi- yöntemi ile analiz edilmiştir. Sonuçlarda, AFM1 konsantrasyonu AFM1 bağlama özelliğini önemli ölçüde etkilemiştir. En yüksek uzaklaştırma yüzdesi, 5 ppb AFM1 konsantrasyonu için gözlenmiş ve \% 61,33 olarak bulunmuştur. İnkübasyon süreci boyunca AFM1 bağlanma yüzdesinde önemli bir değişiklik gözlenmemiş olup, bağlanma büyük oranda 30 dakikada tamamlanmıştır. Sonuçlar, Lactobacillus plantarum NRRLB 4496'nın, AFM1 miktarının süt ortamında azaltılması için iyi bir uygulama potansiyeline sahip olduğunu göstermiştir.

Anahtar Kelimeler: Aflatoksin M1, süt, bağlanma, lactobacillus

\section{Aflatoxin M1 (AFM1) Binding Potential of Lactobacillus plantarum NRRLB 4496 in Milk Medium \\ Abstract}

Mycotoxins are secondary metabolites synthesized by some fungi species, and among these toxins, aflatoxins are known to be very dangerous for human and animal health. Aflatoxin M1 (AFM1) contamination plays a critical role in dairy products. The aim of this study was to evaluate the ability of Lactobacillus plantarum NRRLB 4496 to remove AFM1 in skim milk samples. For this purpose different parameters were tested for AFM1 binding; AFM1 concentrations $(0.5,1,2,5,10 \mathrm{ppb})$ and incubation time period (30 min, $1 \mathrm{~h}, 6 \mathrm{~h}, 24 \mathrm{~h}, 48 \mathrm{~h}$ ). The amount of unbound AFM1 remaining in the milk was analyzed by high-performance liquid chromatography with fluorescence detector. In the results, AFM1 concentration significantly effect the AFM1 removal property. The highest removal percentage was observed for $5 \mathrm{ppb}$ AFM1 concentration and it was $61.33 \%$. Maximum AFM1 binding was performed even in $30 \mathrm{~min}$ and there were only slight changes during $24 \mathrm{~h}$ therefore binding was very rapid process. Results demonstrated that Lactobacillus plantarum NRRLB 4496 has good potential application to reduce AFM1 amounts in milk.

Keywords: Aflatoxin M1, milk, binding, lactobacillus

\section{Giriş}

Aflatoksinler (AF), Aspergillus flavus, Aspergillus parasiticus, Aspergillus nomius gibi çeşitli küfler tarafindan üretilen toksik özellikte ikincil metabolitlerdir (Creppy, 2002). Tarımsal ve gida ürünlerindeki aflatoksin oluşumu kullanılabilir besin maddelerin varlığı, su aktivitesi ve sıcaklık gibi çevresel koşullarla ilgili parametrelerle ilişkilidir (Sweeney ve Dobson, 1998). Aflatoksinler, mutajenik, karsinojenik teratojenik, hepatotoksik ve immünsüpresif özellikleri nedeniyle hayvan ve insan sağlığı üzerinde olumsuz sonuçlara yol açan güçlü bir mikotoksin grubudur (Lewis ve ark, 2005; Guimarães ve ark,2018).

Aflatoksinlerin yaklaşık 19 farklı toksik türevi rapor edilmiştir. Aflatoksin B1 (AFB1) 1993 yılında Uluslararası Kanser Araştırmaları Ajansı (IARC) tarafından grup 1A kanserojen ajan olarak sınıflandırılmıştır (Kabak ve ark, 2009). Aflatoksinler, "difurokumarosiklopentenon" ve "difurokumarolakton" gruplarına dahildir. B grubu toksinleri kumarin yapıdaki lakton halkasına eklenmiş siklopentenon halkas1, Aflatoksin M1 ve M2 toksinleri ise, aflatoksin B1 ve B2'nin hidroksi 
türevleridir (Özkaya ve Temiz, 2003) (Şekil 1). Aflatoksinler, Mısır, fıstık, pamuk çekirdeği, pirinç, antepfıstığı, badem, kestane, balkabağı tohumu ve diğer yağlı tohumlar ve sorgum gibi çeşitli gıda kaynaklarına bulaşabilir (Bircan ve ark, 2008; Adibpour ve ark, 2016). AFB1 kontamine yemlerin, laktosyon döneminde süt hayvanları tarafindan tüketilmesi ile AFB1, hayvanların karaciğerinde değişime uğrar ve meme bezlerinden süte AFM1 olarak salgılanır (Güley ve ark, 2013). AFB1' in monohidroksi türevi olan Aflatoksin M1 (AFM1), insan ve hayvan sütü, bebek mamas1, süt tozu, peynir ve yoğurtta bulunabilir (Bulca ve Bircan, 2018;Marrez ve ark, 2018). AFM1, IARC tarafindan grup 1 kanserojen ajan olarak sınıflandırılmıştır (IRAC, 2002).<smiles>COc1cc2c(c3oc(=O)c4c(c13)CCC4=O)C1C=COC1O2</smiles>

Aflatoksin $B_{1}$<smiles>COc1cc2c(c3oc(=O)c4c(c13)CCC4=O)C1(O)C=COC1O2</smiles>

Aflatoksin $\mathrm{M}_{1}$

\section{Şekil 1. Aflatoksin B1 ve Aflatoksin M1' in Kimyasal Yapısı}

Sütte yükssek AFM1 miktarı bir halk sağlığı sorunu olduğu için, birçok ülkede AFM1 için izin verilen AFM1 miktarları ile ilgili yasal düzenlemeler bulunmaktadır. Örneğin, Avrupa Birliği ham süt, 1sıl işlem görmüşs süt ve süt ürünleri imalatı için sütte maksimum $0,05 \mathrm{mg} / \mathrm{kg}$ AFM1 olarak kabul etmektedir (Avrupa Komisyonu, 2010). Türk Gıda Kodeksi Bulaşanlar Tebliğine göre ise; Çiğ süt, 1sıl işlem görmüş süt, süt bazlı ürünlerin üretiminde kullanılan sütlerde de maksimum limit $0,05 \mathrm{mg} / \mathrm{kg}$ AFM1 olarak belirlenmiştir (Türk Gıda Kodeksi, 2011). Yapılan önceki çalışmalarda süt ve süt ürünlerinde saptanan AFM1 miktarları, konunun ciddiyetini yansıtmaktadır. Kosova'da yapılan bir çalışmada toplam 192 süt örneğinin 74'ünde ( \% 38) AFM1 kontaminasyonu olduğu ve 11 örneğin

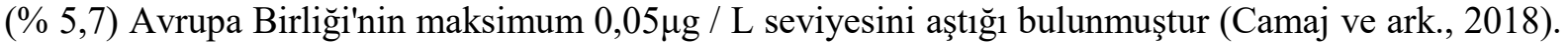
250 anne sütünde yapılan bir araştırmada, AFM1 düzeyleri, 39 örnekte $(\% 15,6) 11,1$ ile 39,3 ng / 1 arasında değişmiştir, bunun 8 örneği (\% 3,2), İran ulusal standart sınırının (25 ng / 1) üzerinde bir seviyede çıkmıştır (Jafari ve ark., 2017). Pakistan' da yapılan bir çalışmada ise toplam 372 süt ve süt ürünleri örneklerinden, yaz mevsiminde toplanan 77 örnekte $(\% 45,5)$, kış mevsiminde toplanan 114 $(\% 56,1)$ örnekte AFM1 saptanmıştır (Iqbal ve ark., 2017). Türkiye' de yapılan bir çalışmada, 7 farklı firmadan toplanan 60 adet devam sütünde enzim bağlı immünosorbent yöntemi ile yapılan AFM1 miktar analizlerinde, Türk Gıda Kodeksi limit değerini aşan 23 örnek tespit edilmiştir (Tuz ve ark., 2017). Ayrıca, aflatoksin varlığının çeşitli peynirlerde de değişen düzeylerde olduğu çeşitli çalışmalarda bildirilmiştir (Bulca ve Bircan, 2013; Güley ve ark, 2013). Bütün bu çalışmalar, süt ve süt ürünlerinde AFM1 varlığının halen problem olarak devam ettiğini göstermektedir. Bu durumda, kontamine olmuş ürünlerde AFM1' in uzaklaştırılması önem kazanmaktadır.

Çeşitli çalışmalarda aflatoksinleri uzaklaştırmak için kimyasal, fiziksel ve biyolojik metotlar önerilmiştir (Sabuncuoğlu ve ark.,2008; Jalili, 2015; Guimaraes ve ark, 2018). Genel olarak, aflatoksinlerin fiziksel, kimyasal ve biyolojik yöntemlerle detoksifikasyonundaki başarı, aflatoksin konsantrasyonu, gıda örneğinin bileşimi ve fizikokimyasal özellikleri (nem içeriği, yağ içeriği, asitlik, doku vb.) gibi birçok faktöre bağlıdır. Bu nedenle, doğru yaklaşımı seçmek çok karmaşıktır. Ayrıca, hemen hemen tüm yöntemlerin dikkate değer kısıtlamaları vardır. Aflatoksinlerin azaltılmasında kimyasal bir bileşiğin ümit verici sonuçlarına rağmen, bu kimyasal bileşikler, istenmeyen toksik kalıntılar üretebilirler. Ayrıca, gıdaların fonksiyonel ve duyusal (doku, tat, aroma, renk) özelliklerinde değişikliklere neden olabilirler. Fiziksel yöntemler ise genellikle daha pahalıdır (Jalili, 2015). Biyolojik yöntemlerde ise doğal olmayan kimyasal maddelerde yaşanan problemlerin ortaya çıkma olasıllı̆̆ı düşüktür. Biyolojik yöntemlerden biri olan degradasyon, spesifik mikroorganizma veya 
enzimler tarafindan toksinin mikrobiyal inaktivasyonuna dayanır. Diğer biyolojik uygulamalardan bir tanesi mikroorganizmaların aflatoksinleri fiziksel adsorpsiyon ile uzaklaştırma prensibine dayanmaktadır. (Sabuncuoğlu ve ark., 2008).

Birçok çalışmada, fosfat tamponlu tuz çözeltisi(PBS) ortamında maya ve laktik asit bakterileri (LAB) toksinleri uzaklaştırma özellikleri araştırılmıştır. (Kabak ve Var, 2006; Ahlberg ve ark.,2015).

$\mathrm{Bu}$ güne kadar yapılan çalışmalarda, LAB'ın AFM1 uzaklaştırma özelliği çoğunlukla PBS ortamında gerçekleştirilmiş ve sınırlı sayıda süt ortamında deneyler gerçekleştirilmiştir (Sadiq ve ark., 2019). Bu çalışmanın amacı, PBS (fosfat tamponlu tuz çözeltisi) ortamında AFM1' i uzaklaştırma potansiyeli bilinen Lactobacillus plantarum NRRLB 4496' suşunun, süt ortamında farklı konsantrasyon AFM1 seviyelerinde toksin bağlama yeteneğinin ve farklı sürelerde AFM1 bağlama kapasitesinin ne şekilde değişkenlik göstereceğini saptamaktır.

\section{Materyal ve Yöntem}

\section{Aflatoksin M1 Standardı}

AFM1 standart solüsyonu R-Biopharm Rhone Ltsd'den $1000 \mathrm{ng} / \mathrm{ml}$ konsantrasyonunda $6 \mathrm{ml}$ olarak satın alınmıştır.

\section{Kültür Hazırlama ve Gelişme Koşulları}

Çalışmada kullanılacak bakteri suşu, NRRL kodu ile ABD Tarım Bakanlığı (USDA) kültür koleksiyonlarından temin edilmiştir. Suş olarak Lactobacillus plantarum NRRLB 4496 kullanılmıştır. Araştırmada çalışılacak bakteri konsantrasyonunu hazırlamak amacıyla, derin dondurucuda $-20^{\circ} \mathrm{C}^{\prime} \mathrm{de}$ muhafaza edilen bakteri suşu, MRS sıvı besiyeri (De Man Ragosa and Sharpe) içerisinde $37^{\circ} \mathrm{C}^{\prime} \mathrm{de}, 48$ saat boyunca inkübe edilerek canlandırılmıştır (Martin ve ark., 2004). Canlandırılan bakteri kültürlerinden, seri şekilde yapılan iki pasaj ile taze ve standart büyüme özelliklerine sahip kültürler

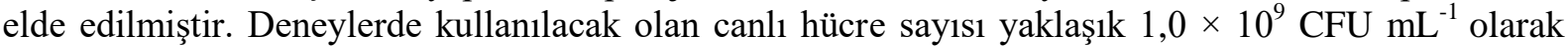
ayarlanmış ve MRS agar kullanılarak yapılan çift tabaka dökme plaka yöntemi ile $37^{\circ} \mathrm{C}$ 'de 48 saat inkübasyon sonunda yapılan sayım ile doğrulanmıştır.

\section{Test Bakterilerinin Hazırlanması}

Geliştirilen bakteri kültürleri 15 dk 1800 g'de santrifüj edilmiş ve saf su ile yıkanmıştır. $\mathrm{Bu}$ işlem iki kez tekrarlanmıştır. Hücreler, deneylerde kullanılacak hacime uygun olarak saf su ile bir süspansiyon haline getirilmiştir. Deneyde kullanılmak üzere bakteriler, sütte meydana gelebilecek olası fermantasyon problemlerinden kaçınmak için, $100{ }^{\circ} \mathrm{C}$ ' de 1 saat otoklav uygulaması ile öldürülmüştür (İsmail ve ark., 2017).

\section{Sütün Aflatoksin M1 ile Kontamine Edilmesi}

AFM1 ara stok solüsyonu $50 \mathrm{ppb}$ olacak şekilde asetonitrilde hazırlanmıştır. Analizlerde kullanılacak konsantrasyon miktarına göre deney tüplerine koyulan AFM1 solüsyonları azot gazı altında uçurularak, asetonitril ortamdan uzaklaştırılmıştır. İçerisinde sadece Aflatoksin standardı kalan deney tüplerinin hacmi UHT yağsız süt ile 2 ml' ye tamamlanmıştır. AFM1 ile kontamine edilen süt örnekleri, 15 dakika boyunca $37^{\circ} \mathrm{C}$ 'de tutulmuş ve 30 sn vortekslenmiştir.

\section{Aflatoksin M1 Bağlanma Deneyi - Konsantrasyonun etkisi}

Analizde 0,5 ppb, $1 \mathrm{ppb}, 2 \mathrm{ppb}, 5 \mathrm{ppb}, 10 \mathrm{ppb}$ konsantrasyonda hazırlanan standartlar kullanılmıştır. Hazırlanan AFM1 kontamine süt örneklerine $100 \mu \mathrm{l}$ bakteri süspansiyonu eklenmiş ve örnekler $37^{\circ} \mathrm{C}^{\prime}$ de 1 saat boyunca inkübe edilmiştir. Analizde kullanılmak üzere tüpler 15 dakika 1800 g' de santrifüj edilmiş ve süpernatant kısmı alınmıştır. Aynı prosedürler negatif kontrolde (süte AFM1 kontemine edilmiş örneklerde bakteri süspansiyonu ilave edilmeden) gerçekleştirilmiştir.

\section{Aflatoksin M1 Bağlanma Deneyi - Zaman etkisi}

Analizde 5 ppb AFM1 konsantrasyonu kullanılmıştır. Bakteri süspansiyonundan $100 \mu 1$, AFM1 içeren $2 \mathrm{~mL}$ UHT yağsız süt örneklerine ilave edilmiş ve vortekslenmiştir. Örnekler; $30 \mathrm{dk}, 1$ sa, 6 sa, $24 \mathrm{sa}$, ve 48 sa boyunca $37^{\circ} \mathrm{C}^{\prime}$ de inkübe edilmiştir. Analizde kullanılmak üzere tüpler 15 dakika 1800 g'de santrifüj edilmiş ve süpernatant alınmıştır. Aynı prosedürler negatif kontrolde (süte AFM1 kontemine edilmiş örneklerde) bakteri süspansiyonu ilave edilmeden gerçekleştirilmiştir.

\section{HPLC ile AFM1 miktarının belirlenmesi}

Sütte kalan AFM1 miktarı immunoaffinite kolonu kullanılarak floresan dedektörlü yüksek performanslı sıv1 kromatografisi (HPLC) ile belirlenmiştir (Kabak ve Var, 2008). Süt ortamından toksinin eldesi ve saflaştırılması için, AFM1' e karşı spesifik antikorları içeren immunoafinite kolonu 
(G1007, Vicam MA, USA) kullanılmıştır. AFM1 kolonları buzdolabından çıkarılmış ve oda sıcaklığına ulaşması sağlanmıştır. İmmünoafinite kolonları açılmış ve kolon 4-5 damla Fosfat tampon tuz çözeltisi damlatılarak kontrol edilmiştir. Hazırlanan $2 \mathrm{ml}+100 \mu$ l'lik numuneler $3 \mathrm{ml} / \mathrm{dk}$ akış hızında kolondan geçirilmiştir. Kolon iki kez $10 \mathrm{~mL}$ su ile yıkanmış ve 3-5 kez hava geçirerek kurutulmuştur. Aflatoksin, 2 adımda tüplere alınmıştır. İlk olarak, $1,25 \mathrm{~mL}$ metanol: asetonitril (2: 3 hacim / hacim) karışımı İmmünoafinite kolonundan geçirimiş ve kendi başına akmasına izin verilmiştir. Aşama 2'de, 1,25 mL HPLC derece kalitede su, toplam 2,5 mL elüat vialini toplamak için kolondan geçirilmiştir. Örneklerde kontamine AFM1 içeriği HPLC metodu ile belirlenmiştir. AFM1 standardı ile farklı beş noktada bir kalibrasyon grafiği $\left(\mathrm{R}^{2}=0.99158\right)$ oluşturulmuştur ve konsantrason hesaplamaları bu şekilde yapılmıştır. Belirli bir süre mobil faz geçirilerek uygulamaya hazır hale getirilen cihaza, önce $\mathrm{AFM}_{1}$ referans standardından, daha sonra eluatlar sıralı olarak $20 \mu \mathrm{l}$ enjeksiyon yapılmıştır. Örneklere ait kromatogramda, standardın kromatogramındaki piklerle aynı alıkonma zamanına sahip pikler olması durumunda, örnekte $\mathrm{AFM}_{1}$ bulunduğuna karar verilmiş ve pik alanlarına bağlı olarak da $\mathrm{AFM}_{1}$ bağlanma oranları hesaplanmıştır. AFM1 içeriğini belirlemek için 3 tekrar analiz gerçekleştirilmiştir. HPLC sistem özellikleri ve çalışma koşulları şu şekildedir: Sistem kontrolör SCL10A vp, izokratik pompa LC-10AT vp, dedektör RF-10AXL, kolon firını CTO-10AS, kolon CTO10AS vp, akış hızı $1 \mathrm{ml} / \mathrm{dk}$, mobil faz Asetonitril 3V: Metanol 2V: Su 5V, kolon sıcaklığ $25{ }^{\circ} \mathrm{C}$, enjeksiyon hacmi $25 \mu 1$, eksitasyon dalga boyu, $360 \mathrm{~nm}$, emisyon dalga boyu $430 \mathrm{~nm}$.AFM1 bağlanma yüzdesi aşağıdaki denklem kullanılarak hesaplanmıştır.

$$
\left\lfloor \% A F M 1=\left[1-\left(\frac{\text { Örneğin AFM1 pik alam })}{\text { Kontrolün AFM1 pik alan }}\right)\right]\right\rfloor * 100
$$

\section{Metot Validasyonu}

Aflatoksin M1 için LOD ve LOQ değerleri sırasılya; $0,11 \mathrm{ppb}, 0,13 \mathrm{ppb}$ tespit edilmiştir. Relatif standart sapma (\%RSD) ve geri kazanım değerleri (\%) Çizelge 3' de gösterilmiştir. Bu çalışmada kullanılan analiz yönteminin performansı AOAC (Association of Analytical Communities) kılavuzuna göre doğrulanmıştır.

\section{İstatistiksel Analiz}

Tüm deneyler üç tekrar şeklinde yapılmış ve sonuçların istatistiksel analizi, SPSS 15 istatistiksel yazılımı (SPSS Inc., Chicago, ABD) kullanılarak yapılmıştır. Sonuçlar arasında anlamlı bir fark olup olmadığ 1 , tek yönlü $T$ Testi metodu ile değerlendirilmiştir. 0,05 ' ten düşük bir p değeri anlamlı olarak kabul edilmiştir.

\section{Bulgular ve Tartışma}

\section{Aflatoksin M1 Bağlanma Deneyi - Konsantrasyonun etkisi}

$100 \mu 1$ ssıl işlem uygulanmış bakteri süspansiyonu ilave edilen, farklı konsantrasyonda hazırlanan AFM1 kontamine süt örneklerinde, Lb. plantarum NRRLB 4496 suşunun AFM1 bağlama kapasitesi Çizelge 1' de verilmiştir. 0,5 ppb, 1 ppb, 2 ppb, 5 ppb, 10ppb AFM1 konsantrasyonlarında Lb. plantarum NRRLB 4496 suşunun AFM1 bağlama kapasitesi sırasıyla, \% 13,7, \% 49,45, \% 41,42, $\%$ 61,33, \% 35,40 olarak tespit edilmiştir. Farklı AFM1 konsantrasyonlarında bağlanma istatistiksel açıdan önemli $(\mathrm{p}<0,05)$ bulunmuştur.

Çizelge 1. Lb. plantarum Aflatoksin M1 bağlanma deneyi - konsantrasyonun etkisi

\begin{tabular}{ll}
\hline Konsantrasyon & Bağlanma Yüzdesi \\
\hline $0,5 \mathrm{ppb}$ & $\% 13,7 \pm 5,39^{\mathrm{a}}$ \\
$1 \mathrm{ppb}$ & $\% 49,45 \pm 9,20^{\mathrm{d}}$ \\
$2 \mathrm{ppb}$ & $\% 41,42 \pm 6^{\mathrm{c}}$ \\
$5 \mathrm{ppb}$ & $\% 61,33 \pm 8,90^{\mathrm{e}}$ \\
$10 \mathrm{ppb}$ & $\% 35,40 \pm 6^{\mathrm{b}}$ \\
\hline
\end{tabular}

*Sonuçlar, üç tekrar örnek için ortalama \pm SD değeridir.

AFM1 konsantrasyonu 5 ppb'den 10 ppb'ye çıtığında bağlanma yüzdesindeki azalma, bakteri hücrelerinin sahip olduğu bağlanma bölgelerinin sayısı ile açıklanabilir. Hücre başına belirli sayıda bağlanma bölgesi olduğu düşünülmektedir. Bu nedenle, yüksek AFM1 konsantrasyonlarında bağlanma bölgelerinin doygunluğa ulaşması ile daha fazla bağlanma gerçekleşmeyecektir. Bu durum, bağlanmanın fiziksel adsorpsiyon ile gerçekleşmesi ile ilişkilidir. 
Abbes ve arkadaşlarının (2013) ,PBS ve sulandırılmış süt ortamında 0,05 $\mu \mathrm{g} / \mathrm{ml}, 0,10 \mu \mathrm{g} / \mathrm{ml}$ ve $0,20 \mu \mathrm{g} / \mathrm{ml}$ konsantrasyonda AFM1 bağlanma deneyi yaptığı çalışmada farklı laktik asit bakteri suşları kullanılmıştır. $L b$. plantarum'un bağlanma oranı, tüm konsantrasyonlarda ilk anda \% 16 civarında hesaplanmış, zaman geçtikçe \% 78,6 oranına ulaştı̆̆ bildirilmiştir (Abbes ve ark., 2013). Farklı laktik asit bakteri suşlarının ve Saccharomyces cerevisiae suşunun $0,05 \mu \mathrm{g} / \mathrm{mL}$, ve $0,10 \mu \mathrm{g} / \mathrm{mL}$ AFM1 konsantrasyonunun süt ortamında bağlanma oranlarının değerlendirildiği bir çalışmada farklı hücre konsantrasyonları da kullanılmış ve hücre konsantrasyonun da bağlanmaya büyük etkisi olduğu belirtilmiştir. $1,0 \times 10^{10} \mathrm{CFU} \mathrm{ml}^{-1}$ hücre konsantrasyonunda $L b$. plantarum suşunun $0,05 \mu \mathrm{g} / \mathrm{ml}$, ve $0,10 \mu \mathrm{g} / \mathrm{mL}$ AFM1 konsantrasyonunda sirasiyla bağlanma yüzdesi \% 76 ve \% 85 olarak hesaplanmıştır (İsmail ve ark., 2017). Kuharic ve arkadaşlarının yaptığı çalışmada ise daha yüksek toksin uzaklaştırma yüzdeleri rapor edilmiş ancak bağlanma deneylerinde daha düşük sicaklık $\left(4{ }^{\circ} \mathrm{C}\right)$ kullanılmıştır. 0,5 $\mu \mathrm{g} / 1 \mathrm{AFM} 1$ kontamine edilmiş taze inek sütüne, 1sıl işlem uygulanan Lb. plantarum suşu ilave edilmiş ve örnekler $0,2,4$ ve 24 saat süre ile inkübe edilmiştir. Sonuçlar sırasıyla \% 83,3, \% $62,7, \%$ 94,5 ve \% 85,7 olarak hesaplanmıştır. Literatürde yer alan bu çalışma sonuçlarının farklılık göstermesi, başlangıç AFM1 konsantrasyonu, kullanılan organizmanın tür ve suşu gibi faktörler ile açıklanabilir.

\section{Aflatoksin M1 Bağlanma Deneyi - Zaman etkisi}

$100 \mu 1$ ssıl işlem uygulanmış bakteri süspansiyonu ilave edilen, 5 ppb konsantrasyonda hazırlanan ve 30 dakika, 1 saat, 6 saat, 24 saat ve 48 saat boyunca $37^{\circ} \mathrm{C}^{\prime}$ de inkübe edilen AFM1 kontamine süt örneklerinde, Lb. plantarum NRRLB 4496 suşunun AFM1 bağlama kapasitesi Çizelge 2 ' de belirtildiği üzere, sırasıyla $\% 46, \% 47, \% 37, \% 45, \% 46$ olarak tespit edilmiştir. Uygulanan tüm süre deneylerinde, Lactobacillus plantarum NRRLB 4496' suşunun, AFM1'i bağlama yetenekleri arasındaki fark istatistiksel açıdan önemsiz ( $\mathrm{p}>0,05)$ bulunmuştur. Şekil 2' de bakteri süspansiyonu ilave edilen ve 6 saat boyunca $37^{\circ} \mathrm{C}^{\prime}$ de inkübe edilen AFM1 kontamine süt örneği, Şekil 3' de ise negatif kontrol numunesi analiz sonuçları kromotogram şeklinde sunulmuştur.

Çizelge 2. Lb. plantarum Aflatoksin M1 bağlanma deneyi - zaman etkisi

\begin{tabular}{ll}
\hline Süre & Bağlanma Yüzdesi \\
\hline $30 \mathrm{dk}$ & $\% 46 \pm 0,05^{\mathrm{a}}$ \\
$1 \mathrm{sa}$ & $\% 47 \pm 0,02^{\mathrm{a}}$ \\
$6 \mathrm{sa}$ & $\% 37 \pm 0,02^{\mathrm{b}}$ \\
$24 \mathrm{sa}$ & $\% 45 \pm 0,17^{\mathrm{a}}$ \\
$48 \mathrm{sa}$ & $\% 46 \pm 0,07^{\mathrm{a}}$ \\
\hline
\end{tabular}

*Sonuçlar, üç tekrar örnek için ortalama \pm SD değeridir.

AFM1 bağlanmasının ilk $30 \mathrm{dk}$ içerisinde gerçekleşmesi ve sonraki süreçte önemli ölçüde değişmemiş olması hücre sayısı, bağlanma bögesi sayısı, AFM1 konsantrasyonu ve bağlanmanın niteliği ile ilgilidir. Pek çok çalışmada bakterilerin mikotoksin bağlama özelliğinin büyük ölçüde kısa sürelerde gerçekleştiği bildirilmektedir (Ahlberg ve ark., 2015). Çalışılan AFM1 konsantrasyonu ve bakteri miktarı için hızlı bir şekilde (30dk içinde) denge durumuna ulaşılmaktadır. Daha yüksek bakteri konsantasyonlarında daha uzun sürelerde dengeye ulaşılabilir.

Panwar ve arkadaşlarının yaptığı araştırmada, 11 probiyotik lactobacillus suşunun PBS çözeltisi ve in vitro yağsız süt ortamında AFM1 bağlama kapasitesi incelenmiştir. 6, 12 ve 24 saat inkübasyon sürelerinde bağlanma oranları \% 4,13 ile \% 64,16 arasında değişmiş̧tir. Yağsız sütün içerisinde in vitro sindirim testi sırasında, $L b$. plantarum canlı hücreleri kullanılarak \% 52 bağlanma gözlenmiştir. (Panwar ve ark., 2018). Bu çalışmada hesaplanan bağlanma yüzdeleri ile yakın değerler tespit edilmiştir. Salah-Abbes ve arkadaşlarının yaptı̆̆ çalışmada ise $37{ }^{\circ} \mathrm{C}^{\prime}$ de 0,12 ve 24 saat inkübasyona bırakılmış $50 \mu \mathrm{g} / \mathrm{ml}$ AFM1 kontamine edilen $L b$. plantarum MONO3 suşunun canlı hücreleri için PBS ortamında bağlanma oranının zamana bağlı olarak arttığ,$\%$ 25,9 oranından, 24 saat sonunda \% 93 oranına ulaştı̆̆ bildirilmiştir (Salah-Abbes ve ark., 2015). Ancak bu çalışmada kullanılan başlangıç AFM1 konstantrasyonun çalışmamızda kullanılan miktardan 10000 kat fazladır ve bu durum zamana bağlı yapılan deneylerde ortaya çıkan farklılıkları açıklayabilir. 
$\mathrm{mV}$

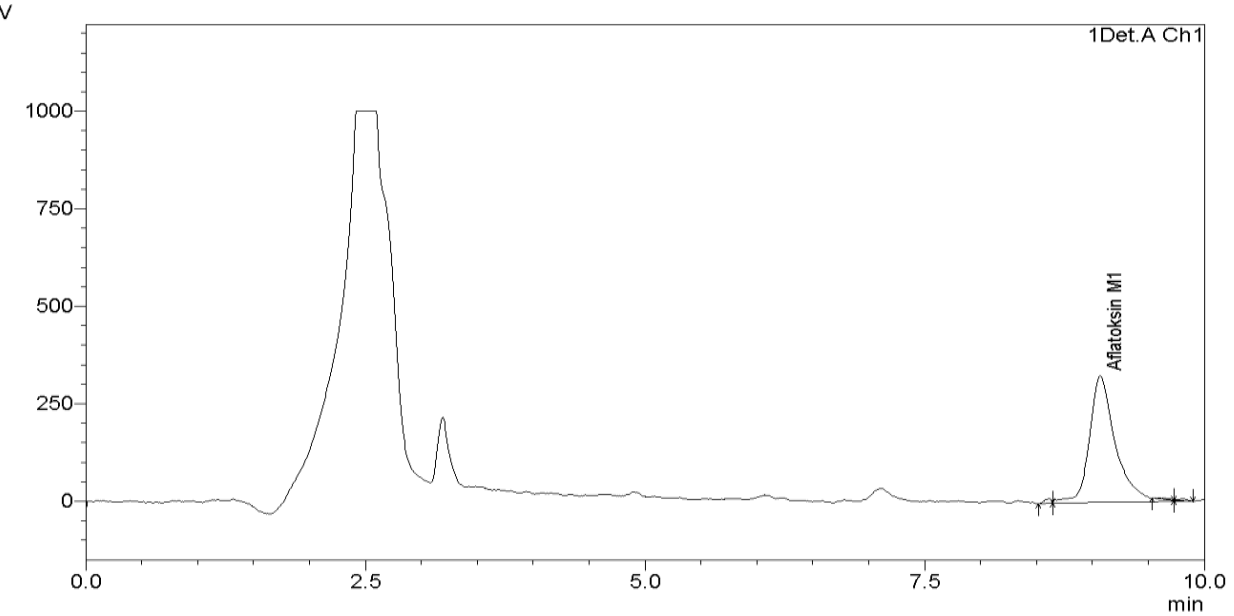

Şekil 2. Bakteri süspansyonu ilave edilen ve 1 saat boyunca $37^{\circ} \mathrm{C}^{\prime}$ de inkübe edilen AFM1 kontamine süt örneği kromotogramı

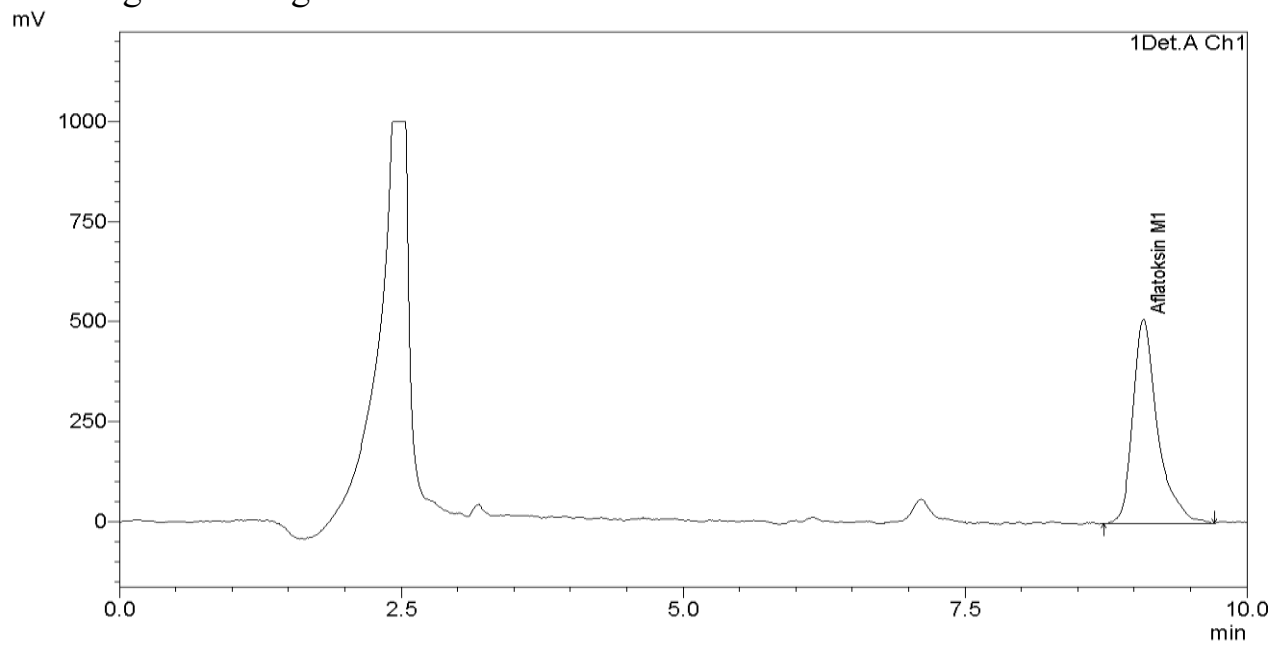

Şekil 3. Bakteri ilave edilmemiş 1 saat boyunca $37^{\circ} \mathrm{C}^{\prime}$ de inkübe edilen negatif kontrol örneği kromotogramı

Çizelge 3. AFM1 konsantrasyonları için yüzde geri kazanım (\%) ve RSD (\%) değerleri

\begin{tabular}{lll}
\hline Konsantrasyon & Geri Kazanım (\%) & RSD (\%) \\
\hline $0,5 \mathrm{ppb}$ & 95 & 1,80 \\
$1 \mathrm{ppb}$ & 93 & 2,18 \\
$2 \mathrm{ppb}$ & 97 & 2,14 \\
$5 \mathrm{ppb}$ & 94 & 1,80 \\
$10 \mathrm{ppb}$ & 98 & 2,32 \\
\hline
\end{tabular}

\section{Sonuç}

Bu çalışmada, Lb. plantarum NRRLB 4496' suşunun, süt ortamında farkl1 konsantrasyon AFM1 seviyelerinde toksin bağlama yeteneğinin ve farklı sürelerde AFM1 bağlama kapasitesinin ne şekilde değişkenlik göstereceği saptanmıştır. AFM1 bağlamada kısa sürelerin yeterli olduğu ve bu durumun uygulama alanında avantaj oluşturabileceği görülmektedir. AFM1 konsantrasyonun ise, AFM1 bağlama kapasitesine önemli bir etkisi olduğu görülmektedir ve bu durum büyük ölçek uygulamalarda, planlama ve dizayn çalışmalarında yol gösterici olacaktır.

Günümüzde, değişen tüketici talepleri ile birlikte doğal koruyucuların önem kazandığı görülmektedir. Lactobacillus plantarum suşlarının biyokoruyucu, biyokontrol ajanı ve probiyotik olarak kullanım potansiyellerinin dışında toksinleri bağlama özellikleri ile hem beslenme alanında hem de toksinlerin gıda ortamlarından uzaklaştırılmasında kullanılabilirler. Toksinlerin kontrolü ile ilgili temel prensip oluşumunun engellenmesi olmasına karşın, süt ürününde AFM1 tehlikesi halen 
devam etmektedir. AFM1 giderilmesinde kimyasal ürünler veya fiziksel işlemler kullanılması yerine Lactobacillus cinsine ait suşların kullanılması ve biyolojik yolla detoksifikasyon gıda ortamında uygulama alanı bulabilir. Bu çalışmada elde edilen veriler AFM1 uzaklaştırabilmek için yapılacak olan büyük ölçekte süt uygulamalarının planlanmasında ve dizaynında faydalı olacaktır.

\section{Kaynaklar}

Abbès, S., Salah-Abbès, J. B., Sharafi, H., Jebali, R., Noghabi, K. A., Oueslati, R., 2013. Ability of Lactobacillus rhamnosus GAF01 toremove AFM1in vitro and tocounteract AFM1 immunotoxicity in vivo. Journal of Immunotoxicology. 10: 279-286.

Adibpour, M., Soleimanian-zad, S., Sarabi-jamab, M., Jajalli, F., 2016. Effect of storage time and concentration of Aflatoxin M1 on toxin binding capacity of L. Acidophilus in fermented milk product. Journal of Agricultural Science and Technology. 18: 1209-1220.

Ahlberg, S.H., Joutsjoki, V., Korhonen, H.J., 2015. Potential of lactic acid bacteria in aflatoxin risk mitigation. International journal of food microbiology. 207: 87-102.

AOAC International, 2002. AOAC Guidelines for Single Laboratory Validation of Chemical Methods for Dietary Supplements and Botanicals

Assaf, J.C., Atoui, A., Khoury, A.E., Chokr, A., Louka, N., 2018. A comparative study of producers for binding of Aflatoxin M1 to Lactobacillus rhamnosus GG. Brazilian Journal of Microbiology. 49: 120-127.

Kabak, B., Var, I., 2008. Factors affecting the removal of aflatoxin M1 from food model by Lactobacillus and Bifidobacterium strains. Journal of Environmental Science and Health, Part B. 43(7):617-624.

Bircan, C., Barringer, S. A., Ulken, U., Pehlivan, R., 2008. Aflatoxin levels in dried figs, nuts and paprika for export from Turkey. International Journal of Food Science \& Technology. 43(8): 1492-1498.Bulca, S., Bircan, C., 2013. Peynirlerde aflatoksin M1 varlığı ve aflatoksin M1 konsantrasyonu üzerine etki eden faktörler. Adnan Menderes Üniversitesi Ziraat Fakültesi Dergisi. 10(1): 31-38.

Camaj, A., Meyer, K., Berisha, B., Arbeshi, T., Haziri, A., 2018. Aflatoxin M1 contamination of cow's milk in five regions of Kosova during 2016. Mytoxin Research. 34: 205-209.

Creppy, E.E., 2002. Update of survey, regulation and toxic effects of mycotoxins in Europe. Toxicology Letters. 127: $19-28$.

European Commission. Commission regulation EC No. 165/2010 of 26 February 2010 amending regulation (EC) No 1881/2006 setting maximum levels for certain contaminants in foodstuffs as regards aflatoxins. Official Journal of the European Union. 2010; L50: 8-12. Erişim tarihi: 10.09.2019 http://eurlex.europa.eu/legal-content/EN/TXT/PDF/?uri=CELEX: \&from=EN

Guimaraes, A., Santiaego, A., Teixeira, J.A., Venancio, A., Abrunhosa, L., 2018. Anti-aflatoxigenic effect of organic acids produced by lactobacillus plantarum. International Journal of Food Microbiology. 264: 31-38.

Güley, Z., Uysal, H.R., Kılıç, S., 2013. Investigation of the presence of aflatoxin M1, aflatoxin B1 and aflatoxigenic moulds in some naturally mould-ripened traditional cheeses. Ege Üniversitesi Ziraat Fakültesi Dergisi. 50(2): 145-152.

IARC, 2002 International Agency for Research on Cancer (IARC). 2002. IARC monographs on the evaluation of carcinogenic risks to humans: Traditional herbal medicines, some mycotoxins, naphthalene and styrene. IARC Scientific Publication. No. 82, IARC, Lyon.

Iqbal, S.Z., Asi, M.R., Malik, N., 2017. The Seasonal Variation of Aflatoxin M1 in milk and dairy products and assesment of dietary intake in Punjab, Pakistan. Food Contol. 79: 292-296.

İsmail, A., Levin, R.E., Riaz, M., Akhtar, S., Gong, Y.Y., Oliveira, C.A.F., 2017. Effect of different microbial concentrations on binding of Aflatoxin M1 and stability testing. Food Control. 73: 492-496

Jafari, T., Fallah, A.A., Kheiri, S., Fadaei, A., Amini, S.A., 2017. Aflatoxin M1 in human breast milk in shahrekord, Iran and association with dietary factors. Food Additives\&Contaminants. Part B, 10(2): 128-136.

Jalili, M., 2005. A Review on aflatoxins reduction in food. Iranian Journal of Health, Safety\&Enviroment. 3(1): 444-449.

Kabak, B., Brandon, E.F., Var, I., Blokland, M., Sips, A.J., 2009. Effects of probiotic bacteria on the bioaccessibility of Aflatoxin $\mathrm{B}_{1}$ and Ochratoxin $\mathrm{A}$ using an in vitro digestion model under fed conditions. Journal of Enviromental Science and Health. Part B. 44(5): 472-480.

Kabak, B., Var, I., 2006. Mikotoksinlerin uzaklaştırılmasında probiyotik laktik asit bakterilerinin kullanımı. Türkiye 9. Gida Kongresi. 24-26 Mayıs, Bolu.

Kuharic, Ž., Jakopović, Ž., Čanak, I., Frece, J., Bošnir, J., Pavlek, Ž., Martina Ivešić, M., Ksenija Markov, K. 2018. Removing aflatoxin M1 from milk with native lactic acid bacteria, centrifugation, and filtration. Arh Hig Rada Toksikol. 69:334-339. 
Lewis, L., Onsongo, M., Njapau, H., Schurz-Rogers, H., Luber, G., Kieszak, S., Rubin, C., 2005. Aflatoxin contamination of outbreak of acute aflatoxicocisin Eastern and Central Kenya. Environ Health Perspect. 113: 1736-1767.

Marrez, D.A., Shahy, E.M., El-Sayed, H.S., Sultan, Y.Y., 2018. Detoxification of Aflatoxin B1 in milk using lactic acid bacteria. Journal of Biological Sciences. 18(3): 144-151.

R. Martín, R., Langa, S., Reviriego, C., Jiménez, E., Marín, M.L., Olivares, M., 2004.The commensal microflora of human milk: new perspectives for food bacteriotherapy and probiotics.Trends in Food Science and Technology. 15:121-127.

Özkaya, Ş., Temiz, A., 2003. Aflatoksinler: Kimyasal yapıları, toksisiteleri ve detoksifikasyonları. Orlab OnLine Mikrobiyoloji Dergisi. 01(01): 1-21.

Panwar, R., Kumar, N., Kashyap, V., Ram, C., Kapila, R., 2018. Aflatoxin M1 detoxification ability of probiotic lactobacilli of Indian origin in in vitro digestion model. Probiotics and Antimicrobial Proteins. 11: 460 469.

Sabuncuoğlu, S.A., Baydar, T., Giray, B., Şahin, G. 2008. Mikotoksinler: Toksik etkileri, degredasyonları, oluşumlarının önlenmesi ve zararlı etkilerinin azaltılması. Hacettepe Üniversitesi, Eczacılık Fakültesi Dergisi. 2 (1): 63-92.

Sadiq, F.A., Yan, B., Tian, F., Zhao, J., Zhang, H., Chen, W., 2019. Lactic acid bacteria as antifungal and antimycotoxigenic agents: A Comprehensive Review. Comprehensive Reviews in Food Science and Food Safety. 18: 1403-1436.

Ben Salah-Abbes, J., Abbes, S., Jebali, R., Haous, Z., Oueslati, R., 2015. Potential preventive role of lactic acid bacteria against Aflatoxin M1 immunotoxicity and genotoxicity in mice. The Journal of Immunology. 12: $107-114$

Sweeney, M.J., Dobson, A.D.W., 1998. Mycotoxin production by Aspergillus, Fusarium and Penicillum species. International Journal of Food Microbiology. 43: 19-28.

TGK. 2011. Türk Gıda Kodeksi. Gıda maddelerinde belirli bulaşanların maksimum seviyelerinin belirlenmesi $\begin{array}{llllll}\text { hakkında teblĭ̆ } & \text { T.C. } & \text { Resmi } & \text { Gazete } & \text { say1: } & 28157 .\end{array}$ http://www.resmigazete.gov.tr/eskiler/2011/12/20111229M3-8-1.pdf Erişim tarihi: 10.08.2019.

Tuz, M.K., Asan, A., Ökten, S., 2017. Devam sütlerinde Aflatoksin M1 varlığının elisa yöntemiyle tespit Edilmesi. Trakya University Journal of Natural Sciences. 18(1): 55-58. 